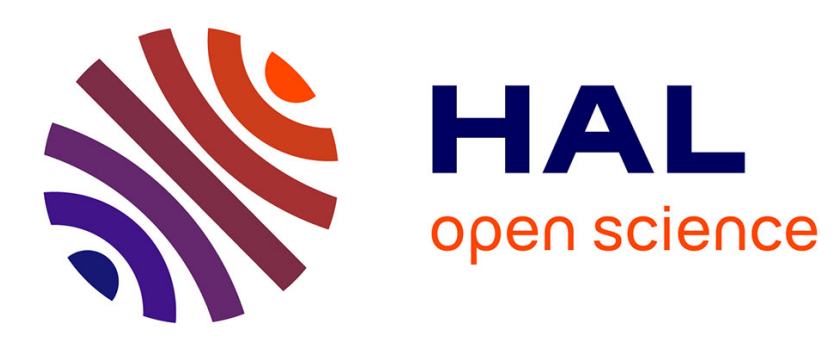

\title{
The influence of temperature and wet weight on the oxygen demand of rainbow trout (Salmo gairdneri R.) in fresh-water
}

A. Muller-Feuga, Jean Petit, J.J. Sabaut

\section{- To cite this version:}

A. Muller-Feuga, Jean Petit, J.J. Sabaut. The influence of temperature and wet weight on the oxygen demand of rainbow trout (Salmo gairdneri R.) in fresh-water. Aquaculture, 1978, 14 (4), pp.355-363. 10.1016/0044-8486(78)90018-2 . hal-01600093

\section{HAL Id: hal-01600093 \\ https://hal.science/hal-01600093}

Submitted on 2 Jun 2020

HAL is a multi-disciplinary open access archive for the deposit and dissemination of scientific research documents, whether they are published or not. The documents may come from teaching and research institutions in France or abroad, or from public or private research centers.
L'archive ouverte pluridisciplinaire HAL, est destinée au dépôt et à la diffusion de documents scientifiques de niveau recherche, publiés ou non, émanant des établissements d'enseignement et de recherche français ou étrangers, des laboratoires publics ou privés.

\section{()(1)(2)}

Distributed under a Creative Commons Attribution - ShareAlikel 4.0 International 


\title{
THE INFLUENCE OF TEMPERATURE AND WET WEIGHT ON THE OXYGEN DEMAND OF RAINBOW TROUT (SALMO GAIRDNERI R.) IN FRESH WATER
}

\author{
A. MULLER-FEUGA* ${ }^{*}$ J. PETIT** and J.J. SABAUT*** \\ *E.D.F., Direction de l'Equipement, 3 rue de Messine, 75008 Paris (France) \\ ** I.N.R.A., Laboratoire de Physiologie des Poissons, 78350 Jouy-en-Josas ((France) \\ ${ }^{* * *}$ G.I.E.E.R.N.A., 33240 Saint-Andre-de-Cubzac (France)
}

(Received 10 January 1978; revised 2 June 1978)

\begin{abstract}
Muller-Feuga, A., Petit, J. and Sabaut, J.J., 1978. The influence of temperature and wet weight on the oxygen demand of rainbow trout (Salmo gairdneri $R$.) in fresh water. Aquaculture, 14: 355-363.
\end{abstract}

Multiple regression analysis was applied to a series of oxygen demand measurements on rainbow trout. It confirmed the determinant influence of temperature and size of fish under standard feeding conditions. Two types of adjustment of oxygen demand in relation to tnose two factors were tested, and one of them was choosen in which the temperature is under an exponential form. This allows the introduction of the $Q_{10}$ concept. The value of $Q_{10}$ is 3.5 when the water temperature is below $10^{\circ} \mathrm{C}$ and 1.7 above $12^{\circ} \mathrm{C}$.

\section{INTRODUCTION}

The water temperature has a determinant influence on the oxygen demand of fish, especially salmonids. Elliot (1969) found the oxygen demand related to the body weight of chinook salmon and to water-flow to be a linear function of temperature.

The influence of fish size was demonstrated, and Liao (1971) suggested an equation introducing that factor.

However, locomotory activity (Beamish and Dickie, 1967; Brett, 1973), salinity (Madan Mohan Rao, 1971), sex and breeding activity (Brett, 1973), and feeding level (Haskell, 1955; Willough by 1968; Sparre, 1976) must also be considered. In fish farming, the first three of these factors are rather constant, and they play a lesser part than temperature and fish size in determining oxygen demand. Whereas size, temperature and food change a lot, sex ratio remains close to 1 , and salinity and locomotory activity remain rather constant. The reproductive metabolism of the fish is not very important yet as the animals are still immature.

Sparre (1976) separates feeding catabolism from fasting catabolism and 
thinks that the oxygen demand should be proportional to the sum of both.

Willoughby (1968) relates oxygen requirements to the total amount of food consumed when fish are fed according to the manufacturers' feeding guide. It gives a good estimate of loading capacities for a fish farm (Fauré, 1976).

Following Liao's method (1971), we tried to find a relationship between oxygen demand and temperature and the size of rainbow trout in fresh water for a given feeding level.

\section{MATERIALS AND METHODS}

Various groups of rainbow trout with an average wet weight of $12-925 \mathrm{~g}$ were acclimated for 2 or 3 days in ponds where measurements were undertaken. The mean load was $5-10 \mathrm{~kg} \mathrm{~m}^{-3}$. Water supply and natural re-oxygenation of these ponds were well known.

While proceeding to measurements, the water-flow was adjusted so as to have $6 \mathrm{mg} \mathrm{l}^{-1}$ dissolved oxygen at the outlet. Measuring started only 5 or $6 \mathrm{~h}$ after the last food intake.

Every 3 min for at least $1 \mathrm{~h}$, the difference in oxygen content between inlet and outlet was checked and, in keeping with the method of Gorin et al. (1977), corrected according to surface exchanges. The average relative error when measuring dissolved oxygen demand (OD) is about $4 \%$.

During the adaptation period, groups were fed in accordance with the usual tables produced by commercial fish-food manufacturers. This feeding level, which produces the maximum growth rate, is a common practice in fish farming. We then assumed the feeding level, which as a factor of variation in OD, to be accounted for. Digestion occurred while OD was measured, but the excitement which follows a food catch had stopped (Petit and Ferron, 1975).

In order to obtain the best regression in the OD of rainbow trout on temperature and wet weight, 52 different observations were made during $95 \mathrm{~h}$, with temperatures ranging from 4 to $22^{\circ} \mathrm{C}$.

The OD is related to fish weight and to time $\left(\mathrm{mg} \mathrm{kg}^{-1} \mathrm{~h}^{-1}\right)$. The average unit wet weight, $p$, is expressed in grammes and temperature, $t$, in ${ }^{\circ} \mathrm{C}$.

\section{RESULTS}

At a constant temperature, the logarithm of the OD is linearly related to the logarithm of $p$.

We then considered an expression such as:

$\log \mathrm{OD}=\mathrm{a} \log p+\mathrm{b}$.

The slopes have two different values, $a_{1}$ and $a_{2}$, when temperatures are under $10^{\circ} \mathrm{C}$ and above $12^{\circ} \mathrm{C}$. In each range of temperature, $\mathrm{b}$, the intercept on the $\mathrm{y}$ axis, seems to increase linearly with temperature, probably giving:

$\log \mathrm{OD}=\mathrm{A} \log p+\mathrm{B} t+\mathrm{C}$ 

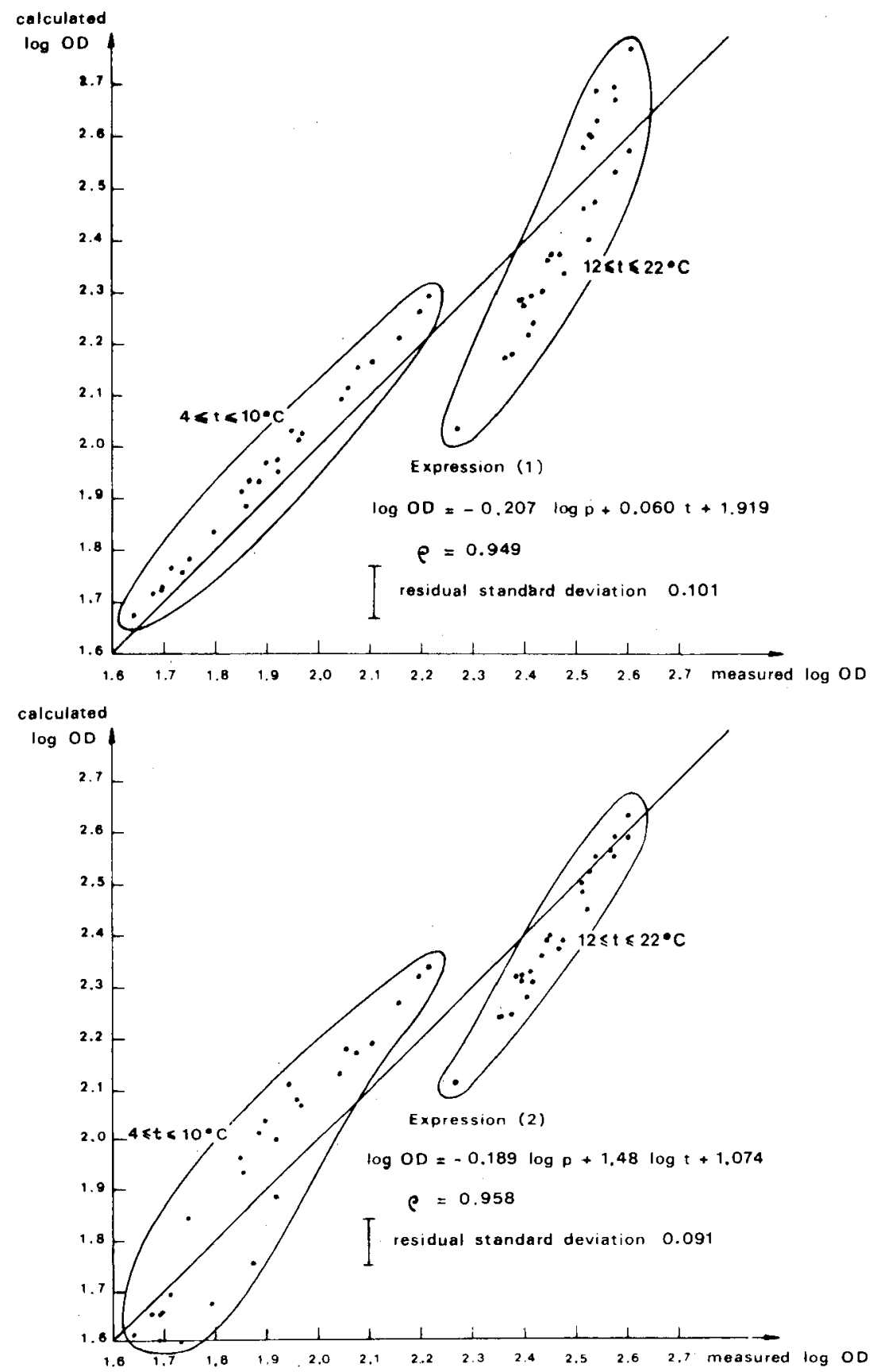

Fig.1. Comparison between calculated and measured oxygen demand (OD) logarithm $\left(4-22^{\circ} \mathrm{C}\right)$. 

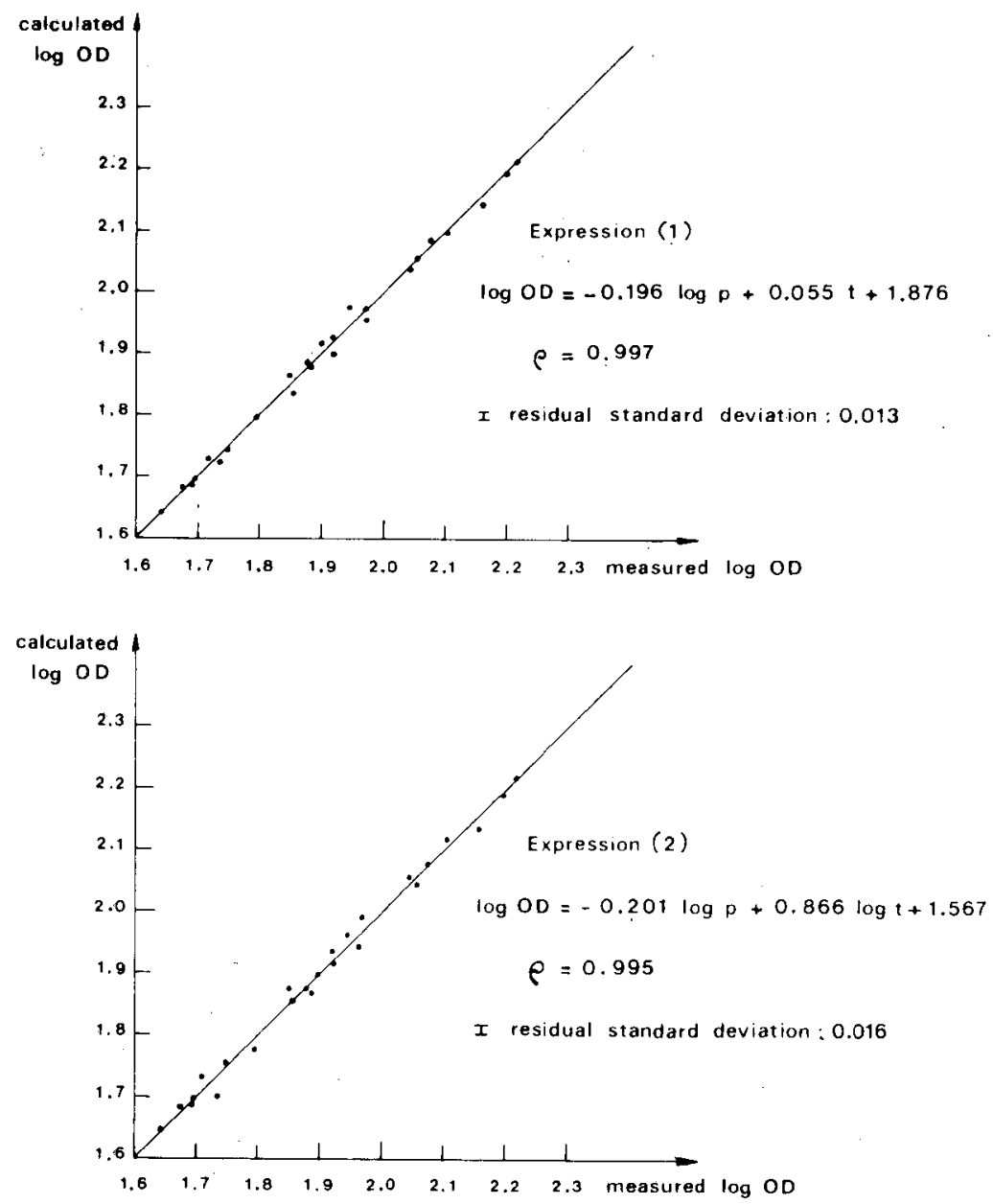

Fig. 2. Comparison between calculated and measured oxygen demand (OD) logarithm $\left(4-10^{\circ} \mathrm{C}\right)$.

As Liao (1971) introduced temperature under a logarithmic form, we also tested the following expression:

$\log \mathrm{OD}=\mathrm{A}^{\prime} \log p+\mathrm{B}^{\prime} \log t+\mathrm{C}^{\prime}$.

We tested (1) and (2) over the whole temperature range. With Fig.1, we can compare the observed values to those calculated through the linear regression coefficients we got for (1) and (2).

According to the graphic analysis, we shall separate the temperatures under $10^{\circ} \mathrm{C}$ from those above $12^{\circ} \mathrm{C}$ since the two groups of dots corresponding to those temperature ranges are clearly discontinuous, even though nothing in the choice of experimental conditions had ever suggested that this might be so. 
When $4 \leqslant t \leqslant 10^{\circ} \mathrm{C}$, multiple regression coefficients for (1) and (2) will be 0.997 and 0.995 . Fig. 2 illustrates the comparison between calculated and observed values. When $12 \leqslant t \leqslant 22^{\circ} \mathrm{C}$, multiple regression coefficients in both expressions are equal to 0.995 (Fig. 3). All the results of the multiple regression analysis applied to our experiments are summarized in Table $\mathrm{I}$.

The only difference between multiple regression coefficients for expressions (1) and (2) will appear when $4 \leqslant t \leqslant 10^{\circ} \mathrm{C}$. To find out if that difference is significant, we compared both regression coefficients through Fischer's function. As the probability of their being identical is over 0.95 , it is impossible to say that one expression will give the better adjustment.

\section{DISCUSSION}

As the expression (2) is identical to that of Liao (1971), we shall compare
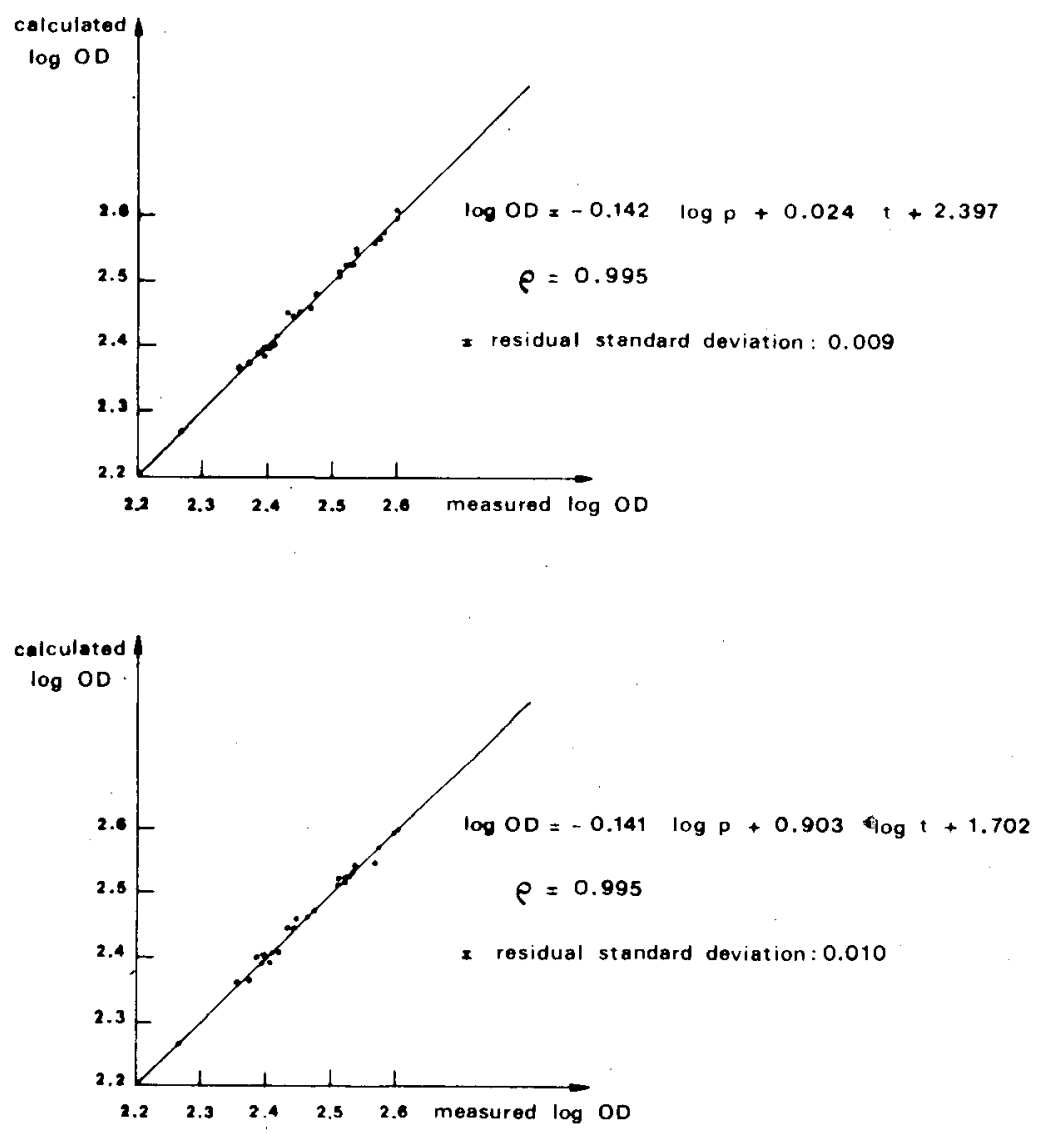

Fig. 3. Comparison between calculated and measured oxygen demand (OD) logarithm $\left(12-22^{\circ} \mathrm{C}\right)$. 
TABLE I

Results of multiple regression analysis

\begin{tabular}{|c|c|c|}
\hline $\begin{array}{l}\text { Temperature } \\
\text { range }\end{array}$ & $\begin{array}{l}\text { Expression (1) } \\
\log O D= \\
A \log p+B t+C\end{array}$ & $\begin{array}{l}\text { Expression (2) } \\
\log \mathrm{OD}= \\
\mathrm{A}^{\prime} \log p+\mathrm{B}^{\prime} \log t+\mathrm{C}^{\prime}\end{array}$ \\
\hline $4 \leqslant t \leqslant 22^{\circ} \mathrm{C}$ & $\begin{array}{l}\mathrm{A}=-0.207 \\
\mathbf{B}=0.060 \\
\mathbf{C}=1.919 \\
\rho=0.949 \\
\tau=0.101\end{array}$ & $\begin{array}{l}\mathrm{A}^{\prime}=-0.189 \\
\mathrm{~B}^{\prime}=1.492 \\
\mathrm{C}^{\prime}=1.074 \\
\rho=0.958 \\
\tau=0.091\end{array}$ \\
\hline $4 \leqslant t \leqslant 10^{\circ} \mathrm{C}$ & $\begin{array}{l}\mathrm{A}=-0.196 \\
\mathrm{~B}=0.055 \\
\mathrm{C}=1.876 \\
\rho=0.997 \\
\tau=0.013\end{array}$ & $\begin{array}{l}\mathrm{A}^{\prime}=-0.201 \\
\mathrm{~B}^{\prime}=0.866 \\
\mathrm{C}^{\prime}=1.567 \\
\rho=0.995 \\
\tau=0.016\end{array}$ \\
\hline $12 \leqslant t \leqslant 22^{\circ} \mathrm{C}$ & $\begin{array}{l}\mathrm{A}=-0.142 \\
\mathrm{~B}=0.024 \\
\mathrm{C}=2.397 \\
\rho=0.995 \\
\tau=0.009\end{array}$ & $\begin{array}{l}\mathbf{A}^{\prime}=-0.141 \\
\mathbf{B}^{\prime}=0.903 \\
\mathbf{C}^{\prime}=1.702 \\
\rho=0.995 \\
\tau=0.010\end{array}$ \\
\hline
\end{tabular}

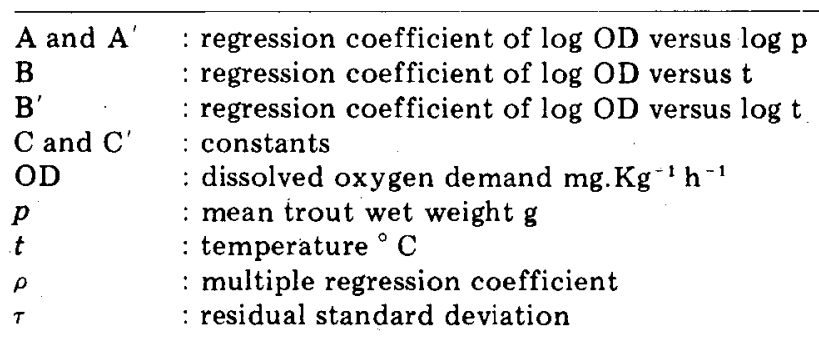

them. Liao studied two ranges of temperature showing a discontinuity near $10^{\circ} \mathrm{C}$; this confirms our own results.

Liao's equation may also take the following form:

$\log \mathrm{O}_{2}=\mathrm{m} \log W+\mathrm{n} \log T+\mathrm{K}^{\prime}$

$\mathrm{O}_{2}=$ oxygen demand for $100 \mathrm{~kg}$ fish wet weight per day $(\mathrm{kg})$

$T \quad=$ water temperature $\left({ }^{\circ} \mathrm{F}\right)$

$W \quad=$ mean wet weight (pounds).

$\mathrm{m}$ should then be equal to our $\mathrm{A}^{\prime}$. The only value Liao kept for $\mathrm{m}(-0.138)$ is similar to the $\mathrm{A}^{\prime}$ value we got for $12 \leqslant t \leqslant 22^{\circ} \mathrm{C}\left(\mathrm{A}^{\prime}=-0.141\right)$.

In our expression (2) and in Liao's equation, temperature appears as a power function and, on the contrary, as an exponent in expression (1). We may choose either expression as both are equivalent; therefore we shall keep ex- 
pression (1), temperature being more often found under an exponential form in physiology. Besides, it will allow the introduction of the $Q_{10}$ concept (activity ratio at $t+10^{\circ} \mathrm{C}$ and $t$ ).

Summing up, we get:

$\mathrm{OD}=\alpha \cdot p^{\beta} \cdot 10^{\gamma t}$

where:

OD : oxygen consumption per hour for $1 \mathrm{~kg}$ fish $\left(\mathrm{mg} \mathrm{kg}^{-1} \mathrm{~h}^{-1}\right)$

$p \quad$ : mean fish wet weight $(\mathrm{g})$

$t$ : temperature $\left({ }^{\circ} \mathrm{C}\right)$

and:

$Q_{10}=10^{10 \gamma}$

The constants obtained for rainbow trout in fresh water are given in Table II. These calculated results can be seen graphically in Fig.4.

\section{TABLE II}

Constants for rainbow trout in fresh water

\begin{tabular}{lll}
\hline & $4 \leqslant t \leqslant 10^{\circ} \mathrm{C}$ & $12 \leqslant t \leqslant 22^{\circ} \mathrm{C}$. \\
\hline$\alpha$ & 75 & 249 \\
$\beta$ & -0.196 & -0.142 \\
$\gamma$ & 0.055 & 0.024 \\
$Q_{10}$ & 3.5 & 1.7 \\
\hline
\end{tabular}

\section{CONCLUSION}

The mathematical model we obtained allows an estimation of the oxygen demand of the rainbow trout in a period of an hour. It is not yet quite perfect because of the indetermination between 10 and $12^{\circ} \mathrm{C}$, and its use is restricted to the feeding level used in practice.

This model gives an OD estimate with a relative error (95\% confidence level) equal to $6 \%$ when $4 \leqslant t \leqslant 10^{\circ} \mathrm{C}$ and $4 \%$ when $12 \leqslant t \leqslant 22^{\circ} \mathrm{C}$, and mainly due to inaccuracy in measuring when applied under to the following conditions:

- a feeding level based on fish-food manufacturers' tables

- clean ponds and good water standards

- more than $6 \mathrm{mg}^{-1}$ oxygen

- an average load between 5 and $10 \mathrm{~kg}^{-3}$.

It leads to the $Q_{10}$ concept, which remains constant at temperatures below $10^{\circ} \mathrm{C}$ and above $12^{\circ} \mathrm{C}$. Its value for the lower temperature range is double that for the upper one. 
OD $\left(\mathrm{mg}: \mathrm{Kg}^{-1} \cdot \mathrm{h}^{-1}\right)$

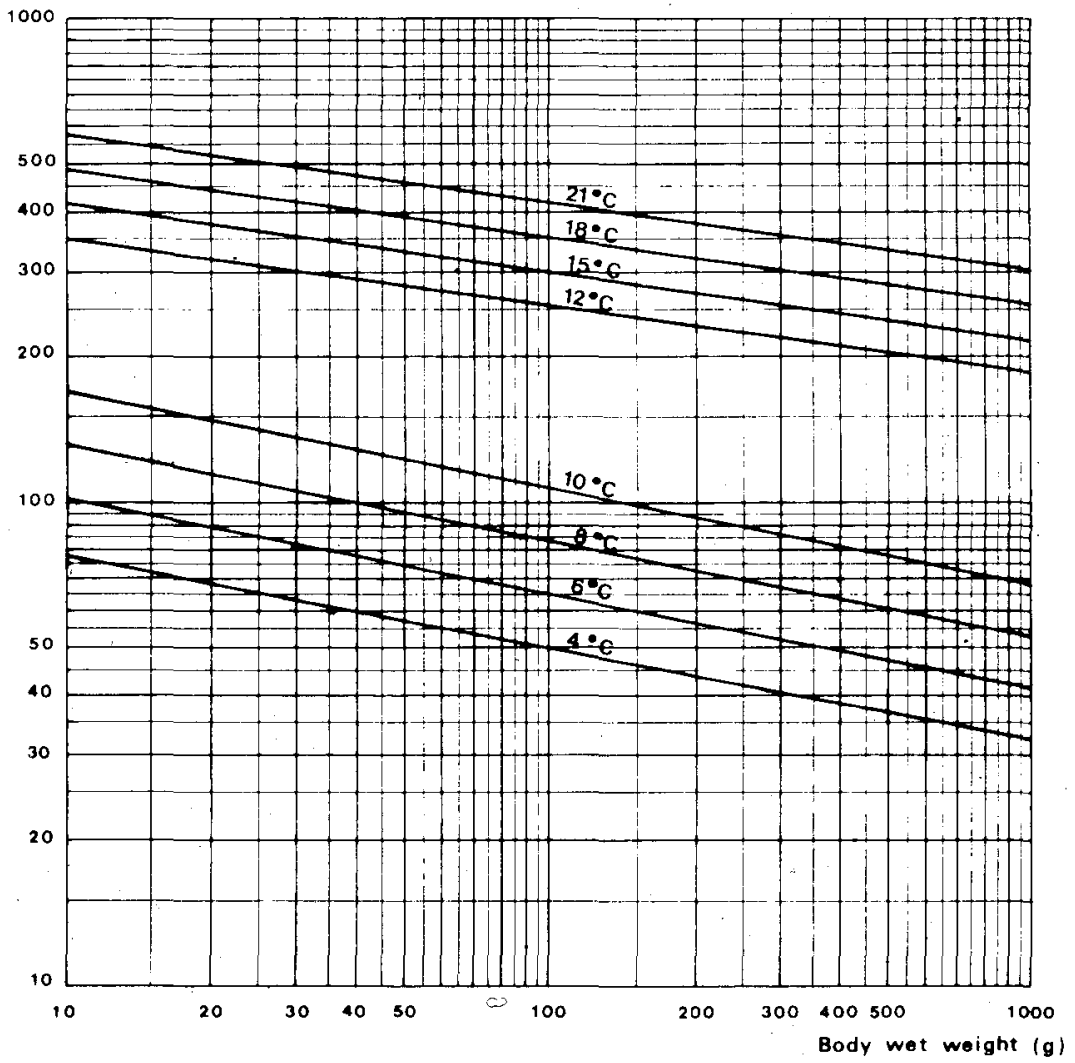

Fig. 4. Oxygen consumption ( $\mathrm{mg} \mathrm{O}_{2}$ per $\mathrm{kg}$ of fish per hour) of rainbow trout related to body wet weight at different temperatures in fresh water.

\section{REFERENCES}

Beamish, F.W.H. and Dickie, L.M., 1967. Metabolism and biological production in fish. In: S. D. Gerking (Editor), The Biological Basis of Freshwater Fish Production. Blackwell, Oxford, Edinburgh, pp. 215-242.

Brett, J.R., 1973. Energy expenditure of sockeye salmon, Oncorhynchus nerka, during sustained performance. J. Fish. Res. Board Can., 30: 1799-1809.

Elliott, J.W., 1969. The oxygen requirements of chinook salmon. Prog. Fish Cult., 31 (2): $67-73$.

Fauré, A., 1976. Bases de la gestion de l'eau en salmoniculture intensive. Piscic. Fr., No 47, pp. 11-54:

Gorin, J., Freville, B., Dereumaux, B.and Harichaux, P., 1977. Méthodes de détermination de la consommation d'oxygène d'un poisson dans les conditions du semi-confinement aquatique (in press).

Haskell, D.C., 1955. Weight of fish per cubic foot of water in hatchery troughs and ponds. Prog. Fish Cult., 17 (3): 117-118. 
Liao, P.B., 1971. Water requirements of Salmonids. Prog. Fish Cult., 33 (4): 210-215.

Madan Mohan Rao, G., 1971. Influence of activity and salinity on the weight dependent oxygen consumption of the rainbow trout Salmo gairdneri. Mar. Biol., 8 (3): 205-212.

Petit, J. and Ferron, J.L., 1975. Les problèmes de l'eau en pisciculture. Part. 2: l'oxygénation des eaux de pisciculture. Méthodes de choix d'un procédé. Piscic. Fr. No 44, pp. 53-62.

Sparre, P., 1976. A markovian decision process applied to optimization of production planning in fish farming. Medd. Dan. Fisk. Havunders: N.S., 7: 111-197.

Willoughby, H., 1968. A method for calculating carrying capacities of hatchery troughs and ponds. Prog. Fish Cult., $30(3)$ : 173-174.

\section{RESUME}

Muller-Feuga, A., Petit, J. et Sabaut, J.J., 1978. Influence de la température et du poids vif sur la demande en oxygène de la truite arc-en-ciel (Salmo gairdneri R.) en eau douce.

Aquaculture, 14: 355-363 (en anglais).

L'analyse des corrélations multiples appliquée à une série de mesures de la demande en oxygène chez la truite arc-en-ciel confirme le caractère déterminant de la température et de la taille des poissons dans les conditions standard d'alimentation. Deux types d'ajustement de la demande en oxygène en fonction de ces deux paramètres sont étudiés. L'un d'entre eux est retenu. Il fait intervenir la température sous une forme exponentielle et permet d'introduire la notion de $Q_{10}$. Celui-ci diffère d'un facteur 2 selon que la température est inférieure à $10^{\circ} \mathrm{C}$ ou supérieure à $12^{\circ} \mathrm{C}$. 